\title{
Co-Expression of Functional P2X4 and P2X7 Receptors at Adult Neural Progenitor Cells of the Mouse Subventricular Zone
}

\author{
Nanette Messemer, Christin Kunert, Peter Illes* and Patrizia Rubini
}

Rudolf Boehm Institute of Pharmacology and Toxicology, University of Leipzig, 04107 Leipzig, Germany

\begin{abstract}
Co-localization of P2X4 and P2X7 subunits has been demonstrated in a number of tissues. It appears that these subunits form functionally interacting homomeric P2X4 and P2X7 receptors rather than heteromeric P2X4/7 receptors. We have recently reported that adult neural progenitor cells (NPCs) of the mouse subventricular zone (SVZ) possess P2X7 receptors. Cultured proliferating NPCs responded to higher concentrations of the prototypic P2X7 agonist dibenzoyl-ATP (Bz-ATP) with inward current, strongly inhibited by the selective P2X7 antagonist A438079, and moderately depressed by the P2X1-3,4 antagonist TNP-ATP, or the selective P2X4 antagonist 5-BDBD. Now we show in addition that ivermectin, a selective allosteric modulator of $\mathrm{P} 2 \mathrm{X} 4$ receptors, uniformly potentiated the effect of lower Bz-ATP concentrations; this potentiation was abolished by 5-BDBD. In conclusion, astrocyte-like cultured SVZ NPCs are endowed with P2X4 and P2X7 receptors shaping the characteristics of these cells with respect to ATP-dependent signalling.
\end{abstract}

Keywords: Neural progenitor cell, P2X4 receptor, P2X7 receptor, membrane current, ligand-gated cation channel.

\section{INTRODUCTION}

Neuroepithelial stem cells in the embryonic nervous system generate most of the neurons and glia in the developing brain [1]. In addition, neurogenesis continues in the adult mammalian brain in specific neurogenic niches, the subgranular zone of the hippocampal dentate gyrus and the subventricular zone (SVZ) of the lateral ventricle, contributing mature neurons to the dentate gyrus and olfactory bulb, respectively $[2,3]$.

Extracellular nucleotides can influence the proliferation and fate decision of neural progenitor cells (NPCs) both during embryonic development and in the adult brain [4,5]. The cellular effects of nucleotides are mediated by seven P2X receptors (P2X1-7 subtypes, which are ligand-gated cation channels; [6]) and eight G-protein-coupled P2Y receptors

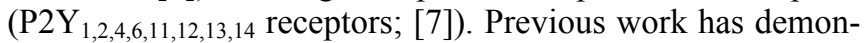
strated that $\mathrm{P}_{2} \mathrm{Y}_{1}$ receptors are present at NPCs of the SVZ in vitro and in situ $[4,8,9]$, causing rapid $\left[\mathrm{Ca}^{2+}\right]_{\mathrm{i}}$ transients and augmenting growth factor-mediated proliferation. Subsequently, P2X7 receptors of SVZ NPCs have been shown to cause apoptosis/necrosis [10] and thereby most likely decrease the neuro- and/or gliogenesis induced by excessive proliferation of NPCs during pathological conditions such as traumatic injury, hypoxia/ischemia, and epilepsy [11].

In the present work, we searched in SVZ NPCs for P2X4 receptors often accompanying $\mathrm{P} 2 \mathrm{X} 7$ receptor-expression in various tissues [12] to find out if the two receptor-types interact with each other to shape ATP-dependent intracellular signalling.

*Address correspondence to this author at the Rudolf Boehm Institute of Pharmacology and Toxicology, University of Leipzig, Haertelstrasse 16-18, 04107 Leipzig, Germany; Tel: (+49)341-9724614; Fax: (+49)341-9724609; E-mail: Peter.Illes@medizin.uni-leipzig.de
Primary cultures of adult NPCs from the SVZ were prepared according to Grimm et al. [8] from 8-14-weeks old $\mathrm{C} 57 \mathrm{Bl} / 6 \mathrm{~N}$ mice. After 7 days of culturing as neurospheres, cells were dispersed and seeded onto coated culture dishes with proliferation medium containing $20 \mathrm{ng} / \mathrm{ml}$ epidermal growth factor and $10 \mathrm{ng} / \mathrm{ml}$ fibroblast growth factor-2.

Whole-cell voltage-clamp recordings were made at room temperature $\left(20-24^{\circ} \mathrm{C}\right)$ on 1-4-days old adherent NPCs, using an Axopatch 200B patch clamp amplifier (Molecular Devices). The pipette solution contained (in $\mathrm{mM}$ ): K-gluconate $140, \mathrm{NaCl} 10, \mathrm{CaCl}_{2} 0.2, \mathrm{MgCl}_{2}$ 2.3, HEPES 10, EGTA 10 , Mg-ATP 4, Li-GTP 0.3 (pH 7.2, with KOH). For seal formation and some initial experiments, we used a normal artificial cerebrospinal fluid (aCSF; in $\mathrm{mM}$ ): $\mathrm{NaCl} 140, \mathrm{KCl} 2.5$, $\mathrm{CaCl}_{2} 1, \mathrm{MgCl}_{2}$ 1.2, HEPES 25, glucose 10.5 (pH 7.3, with $\mathrm{NaOH})$. For low $\mathrm{X}^{2+}$ solution $\mathrm{MgCl}_{2}$ was omitted, and the concentration of $\mathrm{CaCl}_{2}$ was decreased to $0.1 \mathrm{mM}$. Pipettes had resistances of 3-8 M $\Omega$. A holding potential of $-80 \mathrm{mV}$ was selected.

Agonists, antagonists, and allosteric modulators were applied locally by means of a computer-controlled solenoid valve-driven pressurized superfusion system (DAD-12, ALA Scientific Instruments). Bz-ATP and ivermectin were from Sigma-Aldrich, while A-438079, 5-BDBD and TNP-ATP were from Tocris.

In a first series of experiments, we applied Bz-ATP (300 $\mu \mathrm{M})$ onto NPCs for $5 \mathrm{~s}$ every $2 \mathrm{~min}$ in a low $\mathrm{X}^{2+}$ external solution. Previously we have shown that a low $\mathrm{X}^{2+}$ medium markedly increased the effect of Bz-ATP when compared with measurements in a normal $\mathrm{Ca}^{2+} / \mathrm{Mg}^{2+}$-containing medium, and repetitive application of Bz-ATP with the above time-schedule resulted in stable responses [10]. Thus, the divalent cations $\mathrm{Ca}^{2+}$ and $\mathrm{Mg}^{2+}$ depressed the Bz-ATPinduced current responses in agreement with their reported influence on native and recombinant $\mathrm{P} 2 \mathrm{X} 7$ receptors [13]. 

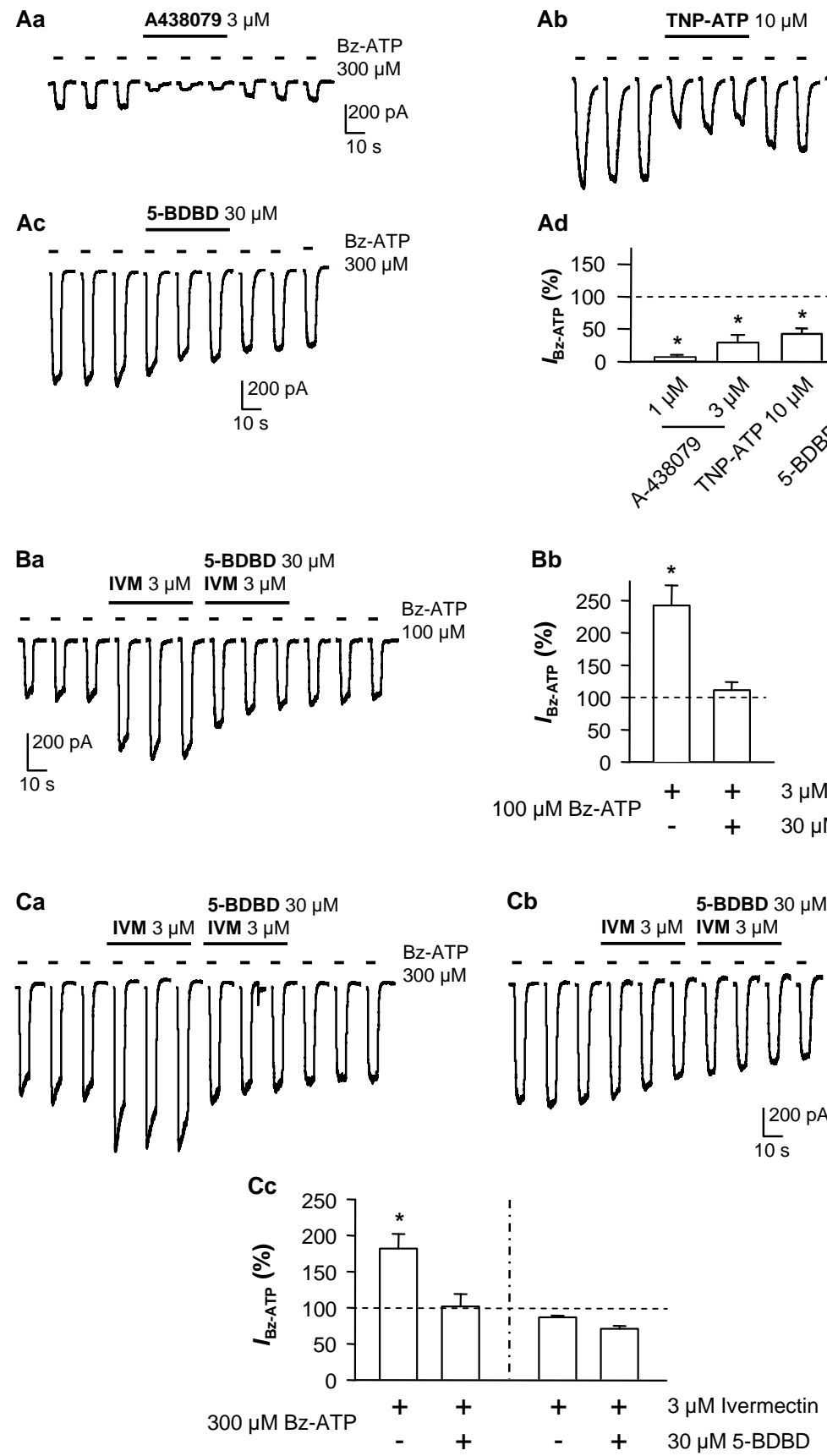
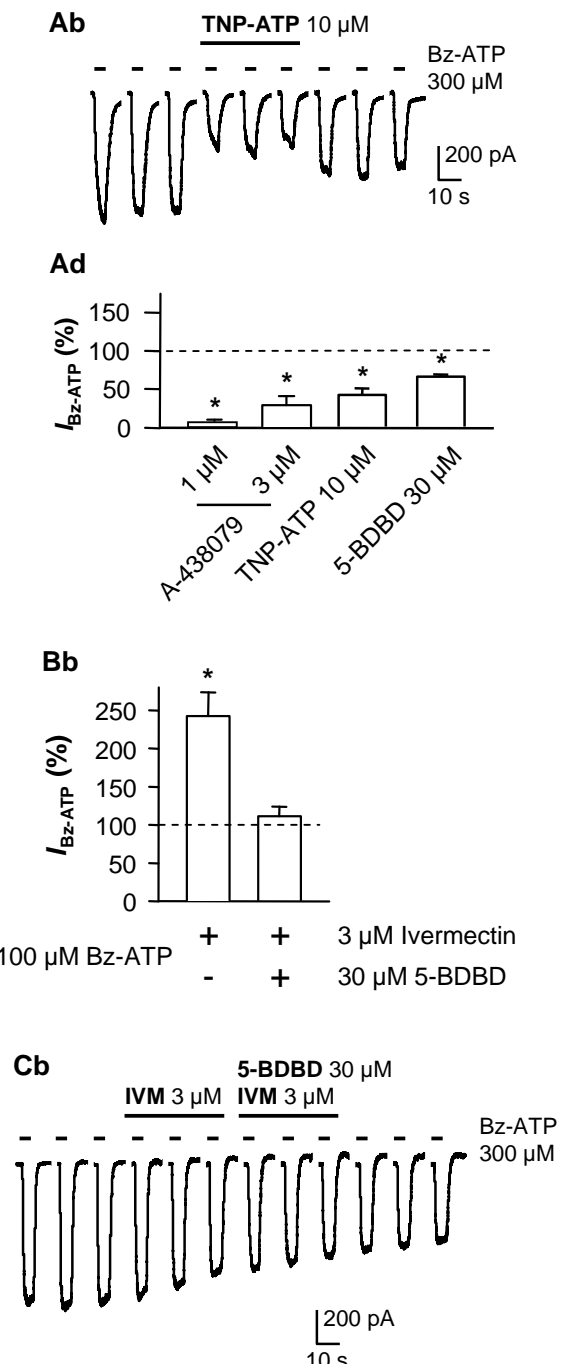

Fig. (1). Functional P2X7 and P2X4 receptors in undifferentiated, cultured neural progenitor cells (NPCs) prepared from the subventricular zone of the adult mouse brain. The holding potential in the whole-cell mode of the patch-clamp recording was $-80 \mathrm{mV}$. Stable concentrations of Bz-ATP $(300$ or $100 \mu \mathrm{M})$ were applied every $2 \mathrm{~min}$ for $5 \mathrm{~s}$. All antagonists or allosteric modulators were superfused for 6 min in total. (A) Inhibition by A-438079 $(3 \mu \mathrm{M})$, TNP-ATP $(10 \mu \mathrm{M})$ and 5-BDBD $(30 \mu \mathrm{M})$ of the Bz-ATP $(300 \mu \mathrm{M})$-induced currents. Representative tracings (a-c) were recorded in this and all other panels of this Fig. from separate cells. Mean \pm S.E.M. of 6-8 cells from 2 culture dishes each (d). In these and all following experiments the change by the antagonist/modulator of the $3^{\text {rd }} \mathrm{Bz}$-ATP current response was compared with the time matched current response in the absence of antagonists/modulators. ${ }^{*} \mathrm{P}<0.05$; statistically significant difference from $100 \%$ (ANOVA, Holm-Sidak test). (B) Increase by ivermectin $(3 \mu \mathrm{M})$ of the Bz-ATP $(100 \mu \mathrm{M})$ currents and its antagonism by 5-BDBD (30 $\mu \mathrm{M})$. Representative tracings (a). Mean \pm S.E.M. of 8 cells from 2 culture dishes (b). ${ }^{*} \mathrm{P}<0.05$; statistically significant difference from $100 \%$ (ANOVA, HolmSidak test). (C) Potentiation of Bz-ATP $(300 \mu \mathrm{M})$ currents by ivermectin $(3 \mu \mathrm{M})$ and its antagonism by 5-BDBD $(30 \mu \mathrm{M})$ in a subpopulation of NPCs (a); no effect of ivermectin and 5-BDBD in another subpopulation (b). Representative tracings (a, b). Mean \pm S.E.M. of 12 (left side) and 15 (right side) cells from 3 culture dishes each (c). Ivermectin-sensitive and -insensitive cells were found in either culture dish. $* \mathrm{P}<0.05$; statistically significant difference from $100 \%$ (ANOVA, Holm-Sidak test). 
We also showed that under low $\mathrm{X}^{2+}$ conditions the effect of Bz-ATP (0.3-1000 $\mu \mathrm{M})$ was concentration-dependent and $300 \mu \mathrm{M} \mathrm{Bz-ATP}$ was a submaximal concentration of this agonist at all cells investigated. Both P2X7 (A-438079) and P2X4 (TNP-ATP; 5-BDBD) receptor antagonists decreased the effect of Bz-ATP (Fig. 1Aa-d), in a manner which only slowly reversed on washout. The inspection of recordings from separate cells demonstrated that the amplitude of the Bz-ATP $(300 \mu \mathrm{M})$-induced currents exhibited a considerable scatter (compare Figs. 1Aa, b and c). Therefore, in all experiments the change by the antagonist/modulator of the $3^{\text {rd }}$ Bz-ATP current response was compared with the time matched current response in the absence of antagonists/modulators [10]. It is noteworthy that whereas A438079 and 5-BDBD are highly selective for P2X7 and $\mathrm{P} 2 \mathrm{X} 4$ receptors, respectively, TNP-ATP is a P2X1,3 receptor antagonist, which however at higher concentrations blocks also P2X4 receptors [14].

At a relatively low Bz-ATP concentration of $100 \mu \mathrm{M}$, ivermectin $(3 \mu \mathrm{M})$, a selective allosteric modulator of rodent P2X4 receptors [15] potentiated the nucleotide effect in all investigated NPCs (Fig. 1Ba, b). The selective P2X4 receptor antagonist 5-BDBD $(30 \mu \mathrm{M} ;[16])$ abolished the effect of ivermectin. By contrast, at a higher Bz-ATP concentration of $300 \mu \mathrm{M}$, ivermectin acted only in a subpopulation of NPCs; 5-BDBD again reversed the potentiation by ivermectin (Fig. 1 Ca, c). In the residual subpopulation of NPCs, neither ivermectin nor 5-BDBD modified the Bz-ATP current amplitudes in a statistically significant manner (Fig. 1Cc), although there was some decrease of the Bz-ATP responses by ivermectin in the individual experiment shown in (Fig. 1Cb).

The agonistic effect of Bz-ATP in a low $\mathrm{X}^{2+}$ external medium and its antagonism by A- 438079 bears out the existence of P2X7 receptors at mouse SVZ NPCs. Recently published data (stronger agonistic effect of Bz-ATP than of ATP itself; inhibitory interaction between Bz-ATP and the selective P2X7 antagonists Brilliant Blue G and A-438079; dilation of the $\mathrm{P} 2 \mathrm{X} 7$ receptor-channel during long-lasting application of Bz-ATP; no effect of Bz-ATP in NPCs of P2X $7^{-/-}$ mice) are also compatible with the presence of such a receptor at NPCs [10]. Our novel findings relate to the coexpression of $\mathrm{P} 2 \mathrm{X} 7$ and $\mathrm{P} 2 \mathrm{X} 4$ receptors; at a relatively low Bz-ATP concentration all NPCs expressed functional P2X4 receptors sensitive to ivermectin and 5-BDBD in opposite ways.

The overlapping expression of $\mathrm{P} 2 \mathrm{X} 4$ and $\mathrm{P} 2 \mathrm{X} 7$ receptors has been documented in multiple tissues and nonexcitatory cell types, including epithelial cells from the salivary gland, exocrine pancreas, airways, macrophages and microglial cells [12]. Although the reason for this co-expression has not been completely clarified, it is suggested that these receptors play a role in inflammatory regulation [17]. The recent literature is divided about the suggestion whether P2X4 and P2X7 receptors exist as independent homomeric channels interacting with each other or whether they constitute heteromeric P2X4/7 channels. There are a number of arguments for each assumptions, especially since Guo et al. [18] published data on the co-immunopecipitation of P2X4 with P2X7. In addition, it was found that heterologous expression of P2X4 and P2X7 separately did not reproduce all the features of the
ATP activated current recorded in HEK293 cells or salivary epithelial cells unless both receptors were co-expressed $[18,19]$. It was also shown that ivermectin, which potentiates homomeric P2X4 receptor-channels by binding between transmembrane helices near the extracellular side [20] potentiated the effect of ATP at low concentrations but not at high concentrations [19]. This finding is in good agreement with our results documented in (Fig. 1B, C).

Arguments for the opposite view are still more convincing. It has been shown by co-immunoprecipitation that all P2X subunits are able to form heterooligomeric complexes with the exception of P2X7 [21]. Moreover homotrimeric complexes were found to be the dominant assembly state of P2X7 receptors by using subtype-specific antibodies in combination with BN-PAGE to directly visualize $\mathrm{P} 2 \mathrm{X}$ receptor complexes from membrane extracts of native tissues [22]. Lipopolysaccharide (LPS)-induced activation differentially regulated microglial $\mathrm{P} 2 \mathrm{X} 4$ and $\mathrm{P} 2 \mathrm{X} 7$ receptor membrane expression [23]. Eventually, it was concluded based on atomic-force microscopy investigations that these individual homomeric P2X4 and P2X7 receptors closely interact in the plasma membrane [24].

In conclusion, we found that in addition to the previously described P2X7 receptors also P2X4 receptors occur in proliferating mouse NPCs. It is suggested that the failure of BzATP to activate P2X4 receptors in NPCs of $\mathrm{P} 2 \mathrm{X}^{-/-}$mice is due to the strong functional interdependence of $\mathrm{P} 2 \mathrm{X} 4$ and P2X7 receptors. These two receptor types act as sensors of ATP and most likely participate in the reactions of NPCs to inflammatory conditions in the CNS.

\section{CONFLICT OF INTEREST}

The author(s) confirm that this article content has no conflicts of interest.

\section{ACKNOWLEDGEMENT}

This work was supported by a grant of the Deutsche Forschungsgemeinschaft (IL 20/19-1). We are grateful to Prof. Herbert Zimmermann for many helpful discussions.

\section{REFERENCES}

[1] Doetsch F. The glial identity of neural stem cells. Nat Neurosci 2003; 6(11):1127-34.

[2] Götz M, Huttner WB. The cell biology of neurogenesis. Nat Rev Mol Cell Biol 2005; 6(10):777-88.

[3] Zhao C, Deng W, Gage FH. Mechanisms and functional implications of adult neurogenesis. Cell 2008; 132(4):645-60.

[4] Mishra SK, Braun N, Shukla V, et al. Extracellular nucleotide signaling in adult neural stem cells: synergism with growth factormediated cellular proliferation. Development 2006; 133(4):675-84.

[5] Rubini P, Pinkwart C, Franke H, Gerevich Z, Nörenberg W, Illes P. Regulation of intracellular $\mathrm{Ca}^{2+}$ by $\mathrm{P}_{2} \mathrm{Y}_{1}$ receptors may depend on the developmental stage of cultured rat striatal neurons. J Cell Physiol 2006; 209(1):81-93.

[6] Khakh BS, North RA. P2X receptors as cell-surface ATP sensors in health and disease. Nature 2006; 442(7102): 527-32.

[7] Abbracchio MP, Burnstock G, Boeynaems JM, et al. International Union of Pharmacology LVIII: update on the P2Y G proteincoupled nucleotide receptors: from molecular mechanisms and pathophysiology to therapy. Pharmacol Rev 2006; 58(3):281-341.

[8] Grimm I, Messemer N, Stanke M, Gachet C, Zimmermann H. Coordinate pathways for nucleotide and EGF signaling in cultured adult neural progenitor cells. J Cell Sci 2009; 122(Pt 14): 2524-33. 
[9] Suyama S, Sunabori T, Kanki H, et al. Purinergic signaling promotes proliferation of adult mouse subventricular zone cells. J Neurosci 2012; 32(27):9238-47.

[10] Messemer N, Kunert C, Grohmann M, et al. P2X7 receptors at adult neural progenitor cells of the mouse subventricular zone. Neuropharmacology 2013; 73C:122-37.

[11] Suh H, Deng W, Gage FH. Signaling in adult neurogenesis. Annu Rev Cell Dev Biol 2009; 25:253-75.

[12] Dubyak GR. Go it alone no more - P2X7 joins the society of heteromeric ATP-gated receptor channels. Mol Pharmacol 2007; 72(6):1402-5.

[13] Sperlágh B, Vizi ES, Wirkner K, Illes P. P2X7 receptors in the nervous system. Prog Neurobiol 2006; 78(6):327-46.

[14] Jarvis MF, Khakh BS. ATP-gated P2X cation-channels. Neuropharmacology 2009; 56(1): 208-15.

[15] Khakh BS, Proctor WR, Dunwiddie TV, Labarca C, Lester HA. Allosteric control of gating and kinetics at P2X4 receptor channels. J Neurosci 1999; 19(17):7289-99.

[16] Chen K, Zhang J, Zhang W, Zhang J, Yang J, Li K, He Y. ATPP2X4 signaling mediates NLRP3 inflammasome activation: a novel pathway of diabetic nephropathy. Int J Biochem Cell Biol 2013; 45(5): 932-43.

[17] Burnstock G. Purinergic P2 receptors as targets for novel analgesics. Pharmacol Ther 2006; 110(3): 433-54.
[18] Guo C, Masin M, Qureshi OS, Murrell-Lagnado RD. Evidence for functional P2X4/P2X7 heteromeric receptors. Mol Pharmacol 2007; 72(6):1447-56.

[19] Casas-Pruneda G, Reyes JP, Perez-Flores G, Perez-Cornejo P, Arreola J. Functional interactions between P2X4 and P2X7 receptors from mouse salivary epithelia. J Physiol 2009; 587(Pt 12):2887-901.

[20] Silberberg SD, Li M, Swartz KJ. Ivermectin interaction with transmembrane helices reveals widespread rearrangements during opening of P2X receptor channels. Neuron 2007; 54(2): 263-74.

[21] Torres GE, Egan TM, Voigt MM. Hetero-oligomeric assembly of $\mathrm{P} 2 \mathrm{X}$ receptor subunits. Specificities exist with regard to possible partners. J Biol Chem 1999; 274(10): 6653-59.

[22] Nicke A. Homotrimeric complexes are the dominant assembly state of native P2X7 subunits. Biochem Biophys Res Commun 2008; 377(3):803-8.

[23] Raouf R, Chabot-Dore AJ, Ase AR, Blais D, Seguela P. Differential regulation of microglial $\mathrm{P} 2 \mathrm{X} 4$ and $\mathrm{P} 2 \mathrm{X} 7$ ATP receptors following LPS-induced activation. Neuropharmacology 2007; 53(4):496504.

[24] Antonio LS, Stewart AP, Xu XJ, Varanda WA, Murrell-Lagnado $\mathrm{RD}$, Edwardson JM. P2X4 receptors interact with both $\mathrm{P} 2 \mathrm{X} 2$ and P2X7 receptors in the form of homotrimers. Br J Pharmacol 2011; 163(5):1069-77.

Received: April 22, 2013

Revised: July 05, 2013

Accepted: July 21, 2013

(C) Messemer et al.; Licensee Bentham Open.

This is an open access article licensed under the terms of the Creative Commons Attribution Non-Commercial License (http://creativecommons.org/licenses/by-nc/3.0/) which permits unrestricted, non-commercial use, distribution and reproduction in any medium, provided the work is properly cited. 